\title{
A Cross-Linker-Based Poly(Ionic Liquid) for Sensitive Electrochemical Detection of 4-Nonylphenol
}

\author{
Jian Hu ${ }^{1,2}$, Hao Dai ${ }^{1,2}$, Yanbo Zeng ${ }^{2, *}\left(\mathbb{0}\right.$, Yiwen Yang ${ }^{2}$, Hailong Wang ${ }^{2}$, Xudong Zhu ${ }^{2}$, \\ Lei $\mathrm{Li}^{2}{ }^{2 *}$, Guobao Zhou ${ }^{2}$, Ruoyu Chen ${ }^{1, *}$ and Longhua Guo ${ }^{3}$ \\ 1 School of Petrochemical Engineering, Changzhou University, Changzhou 213016, China; \\ 15189761689@163.com (J.H.); 13257926215@163.com (H.D.) \\ 2 College of Biological, Chemical Sciences and Engineering, Jiaxing University, Jiaxing 314001, China; \\ yangyiwen@mail.zjxu.edu.cn (Y.Y.); wanghailong@mail.zjxu.edu.cn (H.W.); zhuxudong9zxd@163.com (X.Z.); \\ gbzhou@mail.zjxu.edu.cn (G.Z.) \\ 3 MOE Key Laboratory for Analytical Science of Food Safety and Biology, Fujian Provincial Key Laboratory of \\ Analysis and Detection Technology for Food Safety, Institute of Nanomedicine and Nanobiosensing, \\ College of Chemistry, Fuzhou University, Fuzhou 350116, China; guolh@fzu.edu.cn \\ * Correspondence: ybzeng@mail.zjxu.edu.cn (Y.Z.); lei.li@mail.zjxu.edu.cn (L.L.); cxdcry@163.com (R.C.); \\ Tel.: +86-573-83646203 (Y.Z.)
}

Received: 15 February 2019; Accepted: 28 March 2019; Published: 2 April 2019

check for updates

\begin{abstract}
In this study, we report a cross-linker-based poly(ionic liquid) (PIL) for the sensitive detection of 4-nonylphenol (4-NP). PIL was poly(1,4-butanediyl-3,3'-bis-l-vinylimidazolium dibromide) (poly $\left.\left(\left[\mathrm{V}_{2} \mathrm{C}_{4}(\mathrm{mim})_{2}\right] \mathrm{Br}_{2}\right)\right) . \quad \operatorname{Poly}\left(\left[\mathrm{V}_{2} \mathrm{C}_{4}(\mathrm{mim})_{2}\right] \mathrm{Br}_{2}\right)$ was prepared via one-step free-radical polymerization. The poly $\left(\left[\mathrm{V}_{2} \mathrm{C}_{4}\left(\mathrm{mim}_{2}\right] \mathrm{Br}_{2}\right)\right.$ was characterized by infrared spectroscopy, Raman spectroscopy, thermal gravimetric analyzer and scanning electron microscope. The poly $\left(\left[\mathrm{V}_{2} \mathrm{C}_{4}(\mathrm{mim})_{2}\right] \mathrm{Br}_{2}\right)$ was then drop-cast onto a glassy carbon electrode (GCE) to obtain poly $\left(\left[\mathrm{V}_{2} \mathrm{C}_{4}(\mathrm{mim})_{2}\right] \mathrm{Br}_{2}\right) / \mathrm{GCE}$. In comparison with a bare GCE, poly $\left(\left[\mathrm{V}_{2} \mathrm{C}_{4}(\mathrm{mim})_{2}\right] \mathrm{Br}_{2}\right) / \mathrm{GCE}$ exhibited higher peak current responses for $\left[\mathrm{Fe}(\mathrm{CN})_{6}\right]^{3-/ 4-}$, lower charge transfer resistance, and larger effective surface area. While comparing the peak current responses, we found the peak current response for 4-NP using poly $\left(\left[\mathrm{V}_{2} \mathrm{C}_{4}(\mathrm{mim})_{2}\right] \mathrm{Br}_{2}\right) / \mathrm{GCE}$ to be 3.6 times higher than a traditional cross-linker ethylene glycol dimethacrylate (EGDMA) based poly(EGDMA) modified GCE. The peak current of poly $\left(\left[\mathrm{V}_{2} \mathrm{C}_{4}(\mathrm{mim})_{2}\right] \mathrm{Br}_{2}\right)$ sensor was linear to 4-NP concentration from 0.05 to $5 \mu \mathrm{M}$. The detection limit of 4-NP was obtained as $0.01 \mu \mathrm{M}(\mathrm{S} / \mathrm{N}=3)$. The new PIL based electrochemical sensor also exhibited excellent selectivity, stability, and reusability. Furthermore, the poly $\left(\left[\mathrm{V}_{2} \mathrm{C}_{4}(\mathrm{mim})_{2}\right] \mathrm{Br}_{2}\right) / \mathrm{GCE}$ demonstrated good 4-NP detection in environmental water samples.
\end{abstract}

Keywords: poly(ionic liquid); cross-linker; electrochemical detection; 4-nonylphenol

\section{Introduction}

Nonylphenol ethoxylates are widely used for manufacturing various commercial products such as detergents, lubricating oil, paints, pesticides, and emulsifier, etc [1]. Nonylphenol ethoxylates degrade to produce 4-nonylphenol (4-NP) in an aquatic environment [2]. Since 4-NP can be produced industrially, naturally and through biodegradation of alkylphenol ethoxylates, the high prevalence of 4-NP in environment has been a grave concern due to its ability to mimic estrogen activity [2]. It is a well-known endocrine disruptor and xenoestrogen, causing serious harm to the reproductive health of human and wildlife [3]. Therefore, detection of 4-NP is of great significance. Various analytical methods including enzyme-linked immunosorbent assay [4], liquid chromatography [5], gas chromatography [6], fluorescence analysis [7] and electrochemical method [8] have been developed 
for the determination of 4-NP. Among these methods, the electrochemical method has received an increasing attention due to its many advantages such as time-saving, low cost, high sensitivity, and real-time detection.

Poly(ionic liquids)s (PILs), a sub-class of polyelectrolytes, are polymeric materials in which the polymer backbone contains an ionic liquid (IL) species in each repeating unit [9]. Therefore, PILs are smart materials having the advantages of ILs (enhanced ionic conductivity and high electrochemical stability) combined with excellent processability and good mechanical performances and resulting from the polymeric structure $[10,11]$. Owing to such unique combination of properties, PILs find applications [12] in diverse fields such as electrochemical supercapacitors [13], catalyst [14], gas adsorption [15], extraction [16-19], capillary electrochromatography [20], electrochemical sensors [21,22] and fluorescent determination [23]. In recent years, PIL-based materials prepared with IL monomer as modifiers for electrochemical sensors have been found to exhibit high sensitivity for analytes [24-27]. For example, Wang and co-workers prepared graphene oxide-poly(1-[3-(N-pyrrolyl) propyl]-3-butylimidazolium bromide) and used it as a modifier to construct an electrochemical sensor of bisphenol A detection [24]. In our previous work, we reported an electrochemical sensor with the composite of reduced graphene oxide and poly(1-vinyl-3-ethylimidazolium tetrafluoroborate) for sensitive detection of phenylethanolamine A [26]. Yu et al. utilized the composite of dual hydroxyl-functionalized poly (ionic liquid) and 2,2'-Azinobis-(3-ethylbenzthiazoline-6-sulfonate) as the support to construct a ratiometric electrochemical biosensor for $\mathrm{Cu}^{2+}$ determination [25].

Although monomer-based PIL composites as modifiers for electrochemical sensors have been extensively investigated [24-27], cross-linker based PILs or only PILs without any functionalization as modifiers for electrochemical sensors have rarely been studied [28-31]. This prompted us to carry out the current research, where we prepared a cross-linker-based PIL poly(1,4-butanediyl-3,3'-bis-1vinylimidazolium dibromide) (poly $\left.\left(\left[\mathrm{V}_{2} \mathrm{C}_{4}(\mathrm{mim})_{2}\right] \mathrm{Br}_{2}\right)\right)$ for sensitive electrochemical detection of $4-\mathrm{NP}$. Poly $\left(\left[\mathrm{V}_{2} \mathrm{C}_{4}(\mathrm{mim})_{2}\right] \mathrm{Br}_{2}\right)$ was synthesized using a simple one-step free-radical polymerization method. The peak current responses of 4-NP using poly $\left(\left[\mathrm{V}_{2} \mathrm{C}_{4}(\mathrm{mim})_{2}\right] \mathrm{Br}_{2}\right)$ and a traditional cross-linker ethylene glycol dimethacrylate based poly (EGDMA) modified glassy carbon electrodes were investigated. Apart from selectivity, stability and reproducibility, we applied poly $\left(\left[\mathrm{V}_{2} \mathrm{C}_{4}(\mathrm{mim})_{2}\right] \mathrm{Br}_{2}\right)$ sensor for 4-NP detection in environmental samples.

\section{Materials and Methods}

\subsection{Materials}

4-Nonylphenol and 2,2'-azobisisobutyronitrile (AIBN) were obtained from Aladdin Industrial Corporation (Shanghai, China). Ethylene glycol dimethacrylate (EGDMA), 1-vinylimidazole, 1,4dibromobutane, 2-nitroaniline, 3-nitroaniline, and 4-nitroaniline were procured from Sigma-Aldrich (St. Louis, MO, USA). IL $\left[\mathrm{V}_{2} \mathrm{C}_{4}(\mathrm{mim})_{2}\right] \mathrm{Br}_{2}$ was prepared in our laboratory. Chitosan was procured from Sinopharm Chemical Regent Co., Ltd. (Shanghai, China). Phosphate buffer was prepared using $\mathrm{NaH}_{2} \mathrm{PO}_{4}$ and $\mathrm{Na}_{2} \mathrm{HPO}_{4}$. Deionized water of $18 \mathrm{M} \Omega \mathrm{cm}$ was applied in the experiments.

\subsection{Instrumentation}

Fourier transform infrared (FT-IR) spectra were obtained with Nexus-470 FT-IR spectrometer (Nicolet, Madison, USA). Surface morphology measurements were performed using a JSM-7500F scanning electron microscope (SEM) (JEOL, Tokyo, Japan). Raman spectra were acquired on a Thermo Scientific DXR2xi Raman spectrometer (Waltham, MA, USA). Thermal gravimetric analysis (TGA) was obtained on a STA-449F3 instrument (Netzsch, Selb, Germany). All electrochemical experiments were accomplished on a CHI660D electrochemical workstation using a three-electrode system, where a modified glassy carbon electrode (GCE) as the working electrode, a platinum wire electrode used as the auxiliary electrode and a saturated calomel electrode (SCE) as the reference electrode. 


\subsection{Preparation of Poly(Ionic Liquid) with $\left[V_{2} \mathrm{C}_{4}(\mathrm{mim})_{2}\right] \mathrm{Br}_{2}$ as Cross-Linker}

Scheme 1 shows the synthesis route of poly $\left(\left[\mathrm{V}_{2} \mathrm{C}_{4}(\mathrm{mim})_{2}\right] \mathrm{Br}_{2}\right)$ as a PIL, involving two steps. IL $\left[\mathrm{V}_{2} \mathrm{C}_{4}(\mathrm{mim})_{2}\right] \mathrm{Br}_{2}$ was first synthesized from 1-vinylimidazole and 1,4-dibromo butane following a previously published method [30,31]. Poly $\left(\left[\mathrm{V}_{2} \mathrm{C}_{4}(\mathrm{mim})_{2}\right] \mathrm{Br}_{2}\right)$ was then prepared using $\left[\mathrm{V}_{2} \mathrm{C}_{4}(\mathrm{mim})_{2}\right] \mathrm{Br}_{2}$ as a cross-linker. $\left[\mathrm{V}_{2} \mathrm{C}_{4}(\mathrm{mim})_{2}\right] \mathrm{Br}_{2}(0.01 \mathrm{~mol})$ and $50 \mathrm{mg}$ of $\mathrm{AIBN}$ were added to $30 \mathrm{~mL}$ of mixed solvent containing acetonitrile and toluene $\left(30 \mathrm{~mL}, \mathrm{~V}_{\text {acetonitrile }}: \mathrm{V}_{\text {toluene }}=1: 1\right)$. The reaction mixture was purged with nitrogen for $30 \mathrm{~min}$ and allowed to polymerize for $24 \mathrm{~h}$ at $60^{\circ} \mathrm{C}$. The obtained product was washed with acetonitrile three times and dried at $60^{\circ} \mathrm{C}$ under vacuum overnight to obtain a white solid of poly $\left(\left[\mathrm{V}_{2} \mathrm{C}_{4}(\mathrm{mim})_{2}\right] \mathrm{Br}_{2}\right)$. For comparison, poly(EGDMA) with traditional cross-linker was synthesized following the same procedure, only replacing $\left[\mathrm{V}_{2} \mathrm{C}_{4}(\mathrm{mim})_{2}\right] \mathrm{Br}_{2}$ by EGDMA.

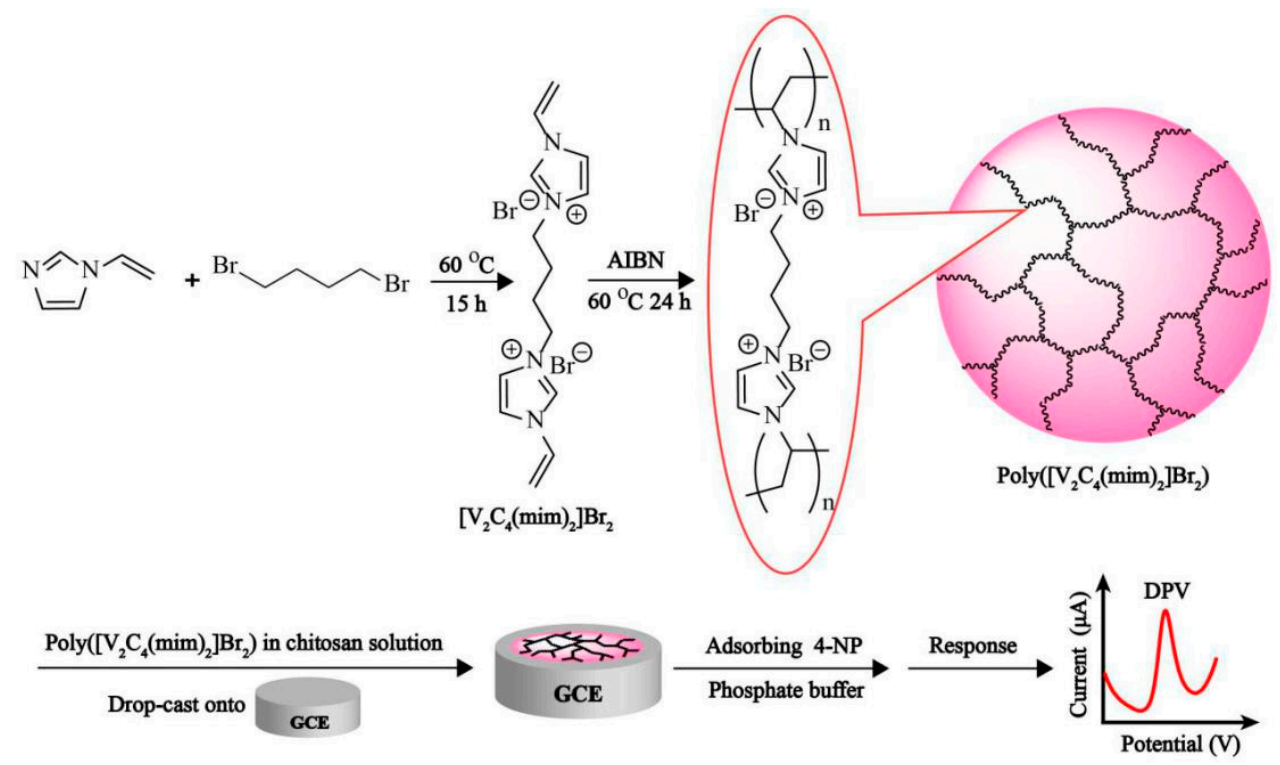

Scheme 1. The synthesis route of poly $\left(\left[\mathrm{V}_{2} \mathrm{C}_{4}(\mathrm{mim})_{2}\right] \mathrm{Br}_{2}\right)$ and the 4-NP detection process using poly $\left(\left[\mathrm{V}_{2} \mathrm{C}_{4}(\mathrm{mim})_{2}\right] \mathrm{Br}_{2}\right) / \mathrm{GCE}$.

\subsection{Electrochemical Measurements}

Scheme 1 shows the 4-NP detection process using poly $\left(\left[\mathrm{V}_{2} \mathrm{C}_{4}(\mathrm{mim})_{2}\right] \mathrm{Br}_{2}\right)$ as an electrochemical modifier. Poly $\left(\left[\mathrm{V}_{2} \mathrm{C}_{4}(\mathrm{mim})_{2}\right] \mathrm{Br}_{2}\right)(3.0 \mathrm{mg})$ was dispersed in HAc $(1 \mathrm{~mL}, 1 \mathrm{M})$ containing chitosan $(0.5 \mathrm{wt} \%)$ by ultrasonication for $30 \mathrm{~min}$. Each suspension $(3.0 \mu \mathrm{L})$ was drop-cast onto a cleaned GCE and dried under an infrared lamp. Chitosan was applied as an adhesive to stabilize poly $\left(\left[\mathrm{V}_{2} \mathrm{C}_{4}(\mathrm{mim})_{2}\right] \mathrm{Br}_{2}\right)$ onto GCE. The modified GCE were incubated with 4-NP in $0.1 \mathrm{M}$ phosphate buffer $(10 \mathrm{~mL}, \mathrm{pH} 6.0)$ for 6 min and measured by DPV from 0.2 to $0.9 \mathrm{~V}$.

\section{Results}

\subsection{Characterization of Poly $\left(\left[\mathrm{V}_{2} \mathrm{C}_{4}(\mathrm{mim})_{2}\right] \mathrm{Br}_{2}\right)$}

Figure 1A illustrates FT-IR spectra of $\left[\mathrm{V}_{2} \mathrm{C}_{4}(\mathrm{mim})_{2}\right] \mathrm{Br}_{2}$, poly $\left(\left[\mathrm{V}_{2} \mathrm{C}_{4}(\mathrm{mim})_{2}\right] \mathrm{Br}_{2}\right)$, EGDMA and poly(EGDMA). The peak at $1634 \mathrm{~cm}^{-1}$ in the FT-IR spectrum of $\left[\mathrm{V}_{2} \mathrm{C}_{4}(\mathrm{mim})_{2}\right] \mathrm{Br}_{2}$ corresponds to exocyclic $C=C$ stretching vibration. The characteristic peaks at 1500,1401 , and $1160 \mathrm{~cm}^{-1}$ for $\left[\mathrm{V}_{2} \mathrm{C}_{4}(\mathrm{mim})_{2}\right] \mathrm{Br}_{2}$ are attributed to $\mathrm{C}=\mathrm{N}, \mathrm{C}=\mathrm{C}$, and $\mathrm{C}-\mathrm{N}$ bonds of the imidazolium cation vibrations [32]. The peaks at $1723,1636,1295$ and $1153 \mathrm{~cm}^{-1}$ are ascribed to $C-O$ stretching vibration of carboxylic ester, $\mathrm{C}=\mathrm{C}, \mathrm{C}-\mathrm{O}$ stretching vibration of symmetric and asymmetric ester [33], respectively. Poly $\left(\left[\mathrm{V}_{2} \mathrm{C}_{4}(\mathrm{mim})_{2}\right] \mathrm{Br}_{2}\right)$ and poly(EGDMA) display similar FT-IR peaks with $\left[\mathrm{V}_{2} \mathrm{C}_{4}(\mathrm{mim})_{2}\right] \mathrm{Br}_{2}$ and EGDMA, respectively. Figure $1 \mathrm{~B}$ shows Raman spectra of poly $\left(\left[\mathrm{V}_{2} \mathrm{C}_{4}(\mathrm{mim})_{2}\right] \mathrm{Br}_{2}\right)$ and poly(EGDMA). The peaks at 2933 and $2955 \mathrm{~cm}^{-1}$ from Figure 1B were due to $\mathrm{CH}_{2}$ stretching vibration [34]. 
Curve a shows the characteristic vibration bands $\left(1429,1343,1022 \mathrm{~cm}^{-1}\right)$ corresponding to the imidazolium cation [34], respectively. The peaks at $1726,1461 \mathrm{~cm}^{-1}$ are ascribed to $\mathrm{C}=\mathrm{O}, \mathrm{CH}_{2}$ bonds of poly(EGDMA) (Curve b) [35]. The results show the successful synthesis of poly $\left(\left[\mathrm{V}_{2} \mathrm{C}_{4}(\mathrm{mim})_{2}\right] \mathrm{Br}_{2}\right)$ and poly(EGDMA). Figure 2 displays the TGA curves of poly $\left(\left[\mathrm{V}_{2} \mathrm{C}_{4}(\mathrm{mim})_{2}\right] \mathrm{Br}_{2}\right)$ and poly(EGDMA). A total weight loss of poly $\left(\left[\mathrm{V}_{2} \mathrm{C}_{4}(\mathrm{mim})_{2}\right] \mathrm{Br}_{2}\right)$ and poly(EGDMA) are $88.9 \%$ and $94.4 \%$ at $800{ }^{\circ} \mathrm{C}$, respectively. The results suggests the thermal instability of poly $\left(\left[\mathrm{V}_{2} \mathrm{C}_{4}(\mathrm{mim})_{2}\right] \mathrm{Br}_{2}\right)$ and poly(EGDMA). Figure 3 presents the SEM image of poly $\left(\left[\mathrm{V}_{2} \mathrm{C}_{4}(\mathrm{mim})_{2}\right] \mathrm{Br}_{2}\right)$, revealing spherical morphology with diameter ranging from 0.65 to $1.85 \mu \mathrm{m}$.
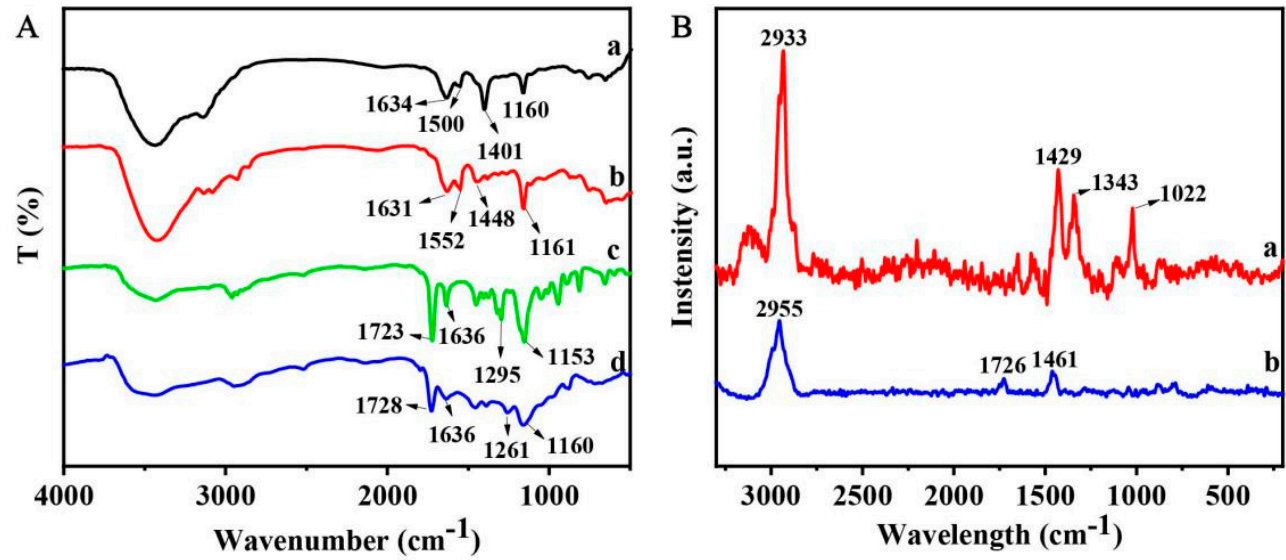

Figure 1. (A) FT-IR spectra of $\left[\mathrm{V}_{2} \mathrm{C}_{4}(\mathrm{mim})_{2}\right] \mathrm{Br}_{2}(\mathrm{a})$, poly $\left(\left[\mathrm{V}_{2} \mathrm{C}_{4}(\mathrm{mim})_{2}\right] \mathrm{Br}_{2}\right)(\mathrm{b})$, EGDMA (c), and poly(EGDMA) (d). (B) Raman spectra of poly $\left(\left[\mathrm{V}_{2} \mathrm{C}_{4}(\mathrm{mim})_{2}\right] \mathrm{Br}_{2}\right)(\mathrm{a})$ and poly(EGDMA) (b).

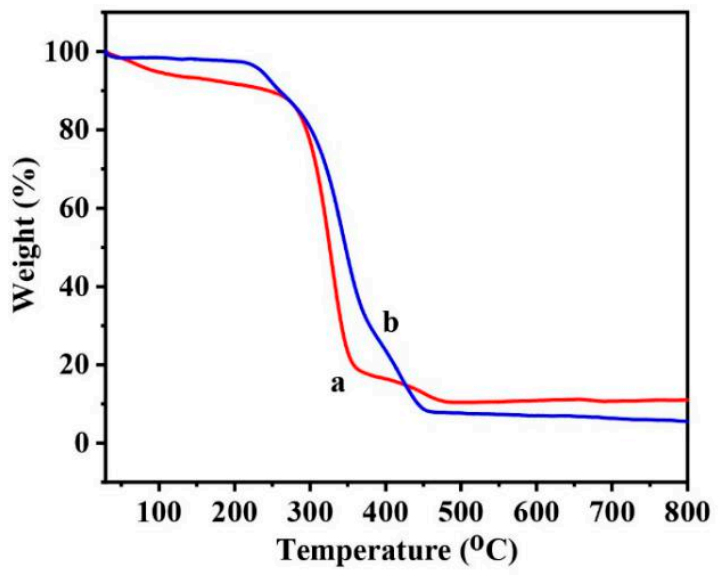

Figure 2. TGA curves of poly $\left(\left[\mathrm{V}_{2} \mathrm{C}_{4}(\mathrm{mim})_{2}\right] \mathrm{Br}_{2}\right)(\mathrm{a})$ and poly(EGDMA) (b).
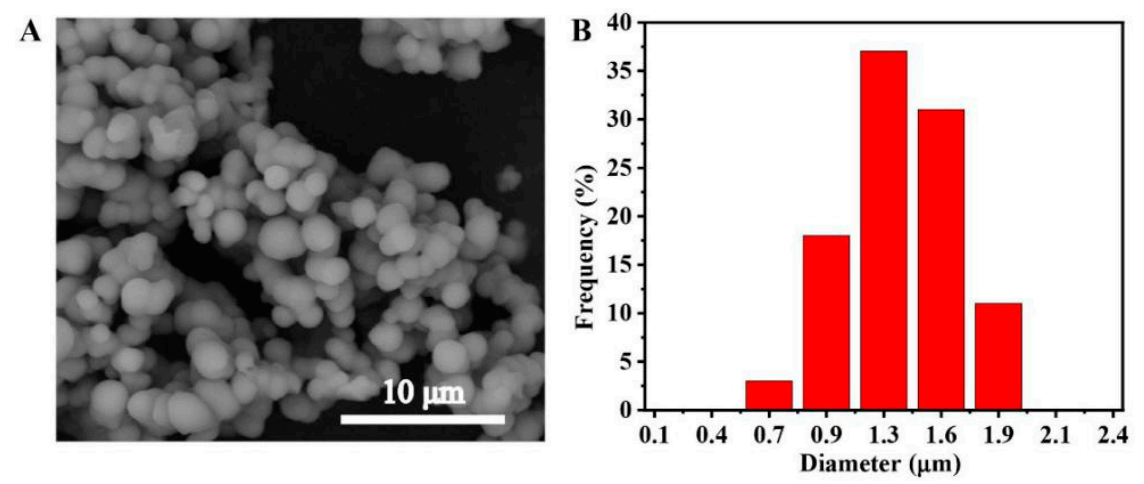

Figure 3. (A) SEM image of poly $\left(\left[\mathrm{V}_{2} \mathrm{C}_{4}(\mathrm{mim})_{2}\right] \mathrm{Br}_{2}\right)$.

(B) Size distribution diagram of $\operatorname{poly}\left(\left[\mathrm{V}_{2} \mathrm{C}_{4}(\mathrm{mim})_{2}\right] \mathrm{Br}_{2}\right)$. 


\subsection{Electrochemical Behavior of Poly $\left(\left[V_{2} \mathrm{C}_{4}(\mathrm{mim})_{2}\right] B r_{2}\right)$}

We studied the electrochemical behaviors of the bare GCE and poly $\left(\left[\mathrm{V}_{2} \mathrm{C}_{4}\left(\mathrm{mim}_{2}\right] \mathrm{Br}_{2}\right) / \mathrm{GCE}\right.$ using cyclic voltammetry (CV). Figure $4 \mathrm{~A}$ shows the $\mathrm{CVs}$ of the bare GCE and poly $\left(\left[\mathrm{V}_{2} \mathrm{C}_{4}\left(\mathrm{mim}_{2}\right] \mathrm{Br}_{2}\right) / \mathrm{GCE}\right.$ in $0.1 \mathrm{M} \mathrm{KCl}$ containing $5.0 \mathrm{mM}\left[\mathrm{Fe}(\mathrm{CN})_{6}\right]^{3-/ 4-}$. Compared with the bare GCE (curve a), poly $\left(\left[\mathrm{V}_{2} \mathrm{C}_{4}(\mathrm{mim})_{2}\right] \mathrm{Br}_{2}\right) / \mathrm{GCE}$ exhibits higher peak current response, suggesting good electrical conductivity of poly $\left(\left[\mathrm{V}_{2} \mathrm{C}_{4}(\mathrm{mim})_{2}\right] \mathrm{Br}_{2}\right)$, which improves the electron transfer kinetics of $\left[\mathrm{Fe}(\mathrm{CN})_{6}\right]^{3-/ 4-}$ at the PIL electrode. In addition, we studied the electrochemical impedance spectroscopy (EIS) of the two electrodes. The charge transfer resistance (Rct) represents the electron transfer kinetics of a redox probe at the electrode surface. We found lower Rct value of poly $\left(\left[\mathrm{V}_{2} \mathrm{C}_{4}(\mathrm{mim})_{2}\right] \mathrm{Br}_{2}\right) / \mathrm{GCE}$ when compared with the bare GCE and attributed the results to the good electron transfer conductivity of poly $\left(\left[\mathrm{V}_{2} \mathrm{C}_{4}(\mathrm{mim})_{2}\right] \mathrm{Br}_{2}\right)$.

The effective surface areas of the bare GCE and poly $\left(\left[\mathrm{V}_{2} \mathrm{C}_{4}(\mathrm{mim})_{2}\right] \mathrm{Br}_{2}\right) / \mathrm{GCE}$ were calculated from the plots of $Q$ vs. $\mathrm{t}^{1 / 2}$, obtained by chronocoulometry (Figure $4 \mathrm{C}$ ) in $0.5 \mathrm{mM} \mathrm{K}_{3}\left[\mathrm{Fe}(\mathrm{CN})_{6}\right]$ following the Anson method [36,37]. We obtained the effective surface areas of the bare GCE and poly $\left(\left[V_{2} \mathrm{C}_{4}(\mathrm{mim})_{2}\right] \mathrm{Br}_{2}\right) / \mathrm{GCE}$ as 0.0669 , and $0.151 \mathrm{~cm}^{2}$ from the slopes of $\mathrm{Q}$ vs. $\mathrm{t}^{1 / 2}$ plot (Figure $4 \mathrm{D}$ ). The results demonstrate the ability of poly $\left(\left[\mathrm{V}_{2} \mathrm{C}_{4}\left(\mathrm{mim}_{2}\right] \mathrm{Br}_{2}\right)\right.$ to increase the effective surface area. Therefore, we can infer that the effective surface area of poly $\left(\left[\mathrm{V}_{2} \mathrm{C}_{4}\left(\mathrm{mim}_{2}\right] \mathrm{Br}_{2}\right) / \mathrm{GCE}\right.$ can enhance the total adsorption ability for 4-NP, thus increasing the detection sensitivity.
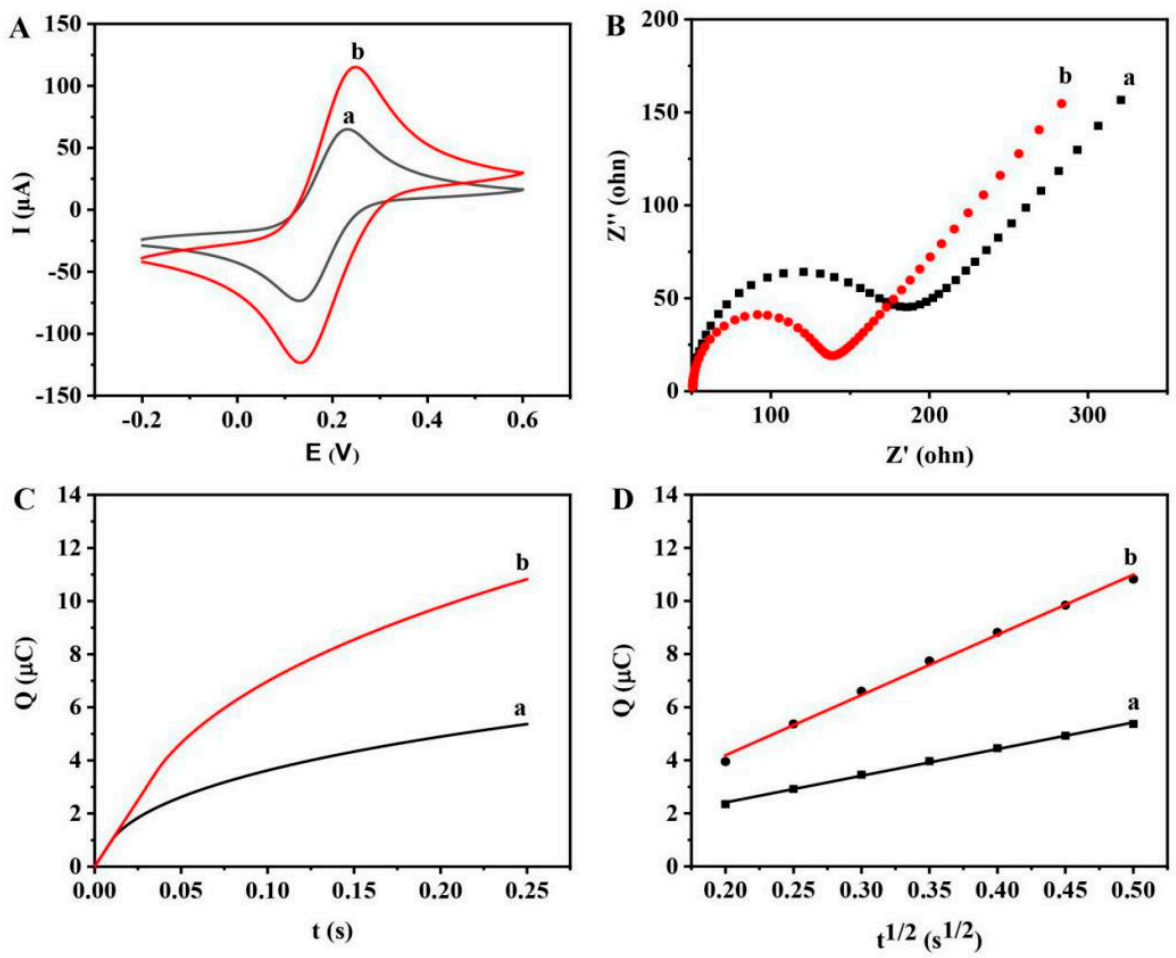

Figure 4. (A) Cyclic voltammograms of bare GCE (a) and poly $\left(\left[\mathrm{V}_{2} \mathrm{C}_{4}(\mathrm{mim})_{2}\right] \mathrm{Br}_{2}\right) / \mathrm{GCE}$ (b) in $0.1 \mathrm{M} \mathrm{KCl}$ containing $5.0 \mathrm{mM}\left[\mathrm{Fe}(\mathrm{CN})_{6}\right]^{3-/ 4-}$. (B) Nyquist plots of bare GCE (a) and poly $\left(\left[\mathrm{V}_{2} \mathrm{C}_{4}(\mathrm{mim})_{2}\right] \mathrm{Br}_{2}\right) / \mathrm{GCE}$ (b) in $0.1 \mathrm{M} \mathrm{KCl}$ containing $5.0 \mathrm{mM}\left[\mathrm{Fe}(\mathrm{CN})_{6}\right]^{3-/ 4-}$. (C) Plot of bare GCE (a) and poly $\left(\left[\mathrm{V}_{2} \mathrm{C}_{4}(\mathrm{mim})_{2}\right] \mathrm{Br}_{2}\right) / \mathrm{GCE}$ (b) in $5.0 \mathrm{mM}\left[\mathrm{Fe}(\mathrm{CN})_{6}\right]^{3-/ 4-}$. (D) Plot of Q-t $\mathrm{t}^{1 / 2}$ curves for bare GCE (a) and poly $\left(\left[\mathrm{V}_{2} \mathrm{C}_{4}(\mathrm{mim})_{2}\right] \mathrm{Br}_{2}\right) / \mathrm{GCE}(\mathrm{b})$ in $5.0 \mathrm{mM}\left[\mathrm{Fe}(\mathrm{CN})_{6}\right]^{3-/ 4-}$.

To highlight the advantage of PIL, we compared the electrochemical responses of poly $\left(\left[\mathrm{V}_{2} \mathrm{C}_{4}(\mathrm{mim})_{2}\right] \mathrm{Br}_{2}\right) / \mathrm{GCE}$ with poly(EGDMA)/GCE. Poly $\left(\left[\mathrm{V}_{2} \mathrm{C}_{4}(\mathrm{mim})_{2}\right] \mathrm{Br}_{2}\right) / \mathrm{GCE}$ and poly(EGDMA)/GCE were incubated with a 4-NP solution in phosphate buffer for $6 \mathrm{~min}$, before carrying out the CV and DPV measurements (Figure 5). We noted oxidation of 4-NP on two electrodes (Figure 5A), but no cathodic signal was observed in the scanned potential range. The result indicates 
an irreversible oxidation process for 4-NP [38]. As shown in Figure 5, poly $\left(\left[\mathrm{V}_{2} \mathrm{C}_{4}(\mathrm{mim})_{2}\right] \mathrm{Br}_{2}\right) / \mathrm{GCE}$ exhibited higher CV and DPV peak current responses for 4-NP than those of poly(EGDMA)/GCE. The peak current response for 4-NP of poly $\left(\left[\mathrm{V}_{2} \mathrm{C}_{4}(\mathrm{mim})_{2}\right] \mathrm{Br}_{2}\right) / \mathrm{GCE}$ was 3.6 times than that of poly(EGDMA)/GCE. We ascribed the higher current response to the excellent electrical conductivity and large effective surface area of poly $\left(\left[\mathrm{V}_{2} \mathrm{C}_{4}(\mathrm{mim})_{2}\right] \mathrm{Br}_{2}\right) / \mathrm{GCE}$.
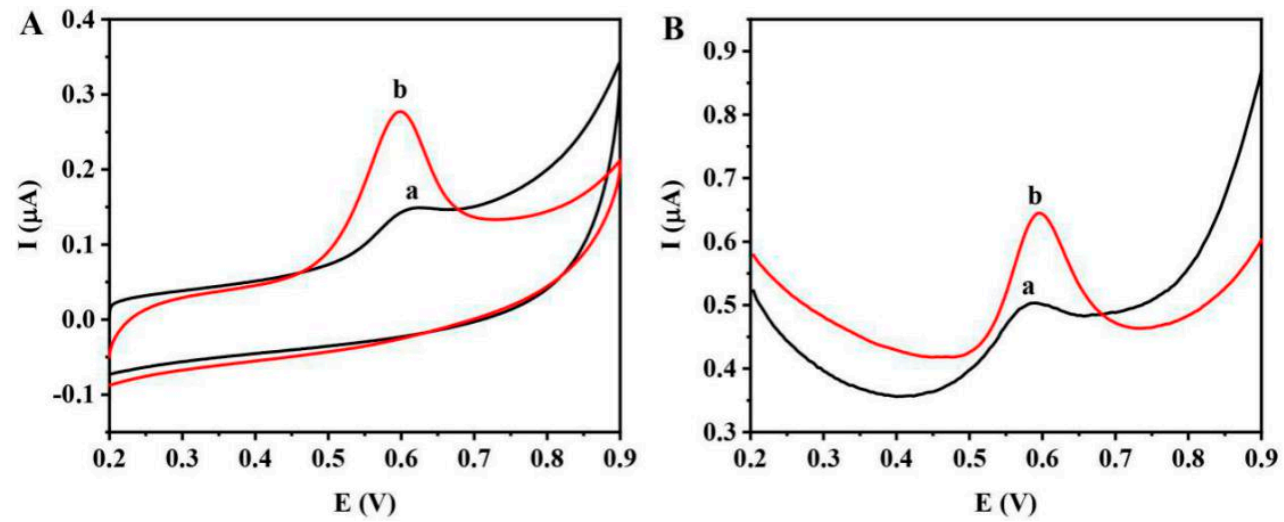

Figure 5. (A) Cyclic voltammograms of poly(EGDMA)/GCE (a) and poly $\left(\left[\mathrm{V}_{2} \mathrm{C}_{4}(\mathrm{mim})_{2}\right] \mathrm{Br}_{2}\right) / \mathrm{GCE}$ (b) after adsorbing $2 \mu \mathrm{M} 4-\mathrm{NP}$ in $0.1 \mathrm{M}$ phosphate buffer $(\mathrm{pH}=6.0)$ for $6 \mathrm{~min}$. Scan rate: $100 \mathrm{mV} / \mathrm{s}$. (B) Differential pulse voltammograms of poly(EGDMA)/GCE (a) and poly $\left(\left[\mathrm{V}_{2} \mathrm{C}_{4}(\mathrm{mim})_{2}\right] \mathrm{Br}_{2}\right) / \mathrm{GCE}$ (b) after adsorbing $2 \mu \mathrm{M} 4-\mathrm{NP}$ for $6 \mathrm{~min}$ in $0.1 \mathrm{M}$ phosphate buffer $(\mathrm{pH}=6.0)$.

\subsection{Optimization of Experimental Conditions}

To investigate the influence of $\mathrm{pH}$ of the test solution on the current of 4-NP, we measured the DPV of $2 \mu \mathrm{M}$ 4-NP at the poly $\left(\left[\mathrm{V}_{2} \mathrm{C}_{4}(\mathrm{mim})_{2}\right] \mathrm{Br}_{2}\right) / \mathrm{GCE}$ over the $\mathrm{pH}$ range of $4-8$. As shown in Figure $6 \mathrm{~A}$, the peak current increased with $\mathrm{pH}$ from 4.0 to 6.0; however, we observed a decrease in the peak current beyond pH 6. Hence, we selected pH 6.0 as the optimum pH for subsequent experiments.
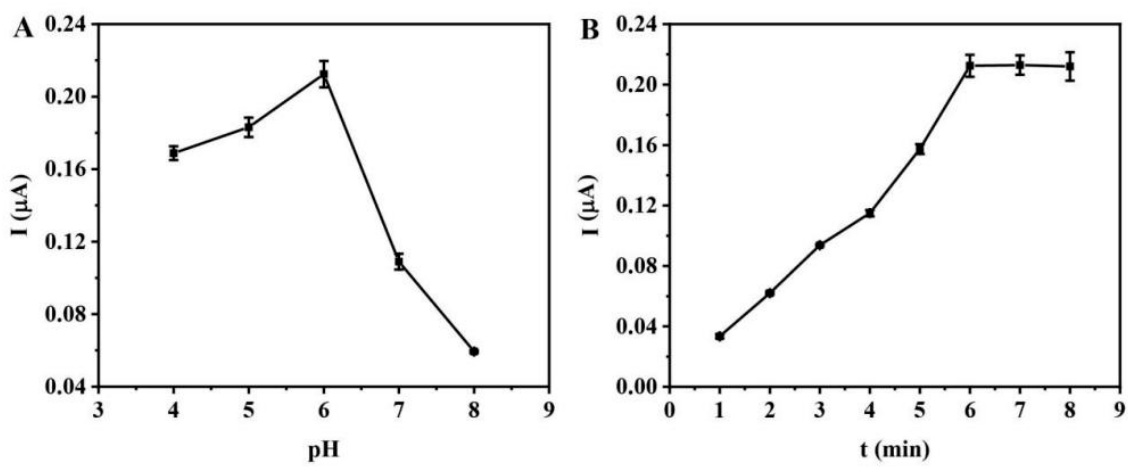

Figure 6. The influence of test solution $\mathrm{pH}(\mathbf{A})$ and incubation time (B) on DPV peak currents at poly $\left(\left[\mathrm{V}_{2} \mathrm{C}_{4}(\mathrm{mim})_{2}\right] \mathrm{Br}_{2}\right) / \mathrm{GCE}$ after incubating in $2 \mu \mathrm{M}$ 4-NP in phosphate buffer.

Moreover, Figure 6B shows increase in the peak current response from until 6 min before reaching a plateau. This indicates that the poly $\left(\left[\mathrm{V}_{2} \mathrm{C}_{4}(\mathrm{mim})_{2}\right] \mathrm{Br}_{2}\right) / \mathrm{GCE}$ was saturated by $4-\mathrm{NP}$ adsorption. Thus, further accumulation of 4-NP onto the electrode (beyond $6 \mathrm{~min}$ ) did not contribute to the enhancement of peak current. Based on our findings, we employed an optimum accumulation time of $6 \mathrm{~min}$ for 4-NP adsorption onto the poly $\left(\left[\mathrm{V}_{2} \mathrm{C}_{4}(\mathrm{mim})_{2}\right] \mathrm{Br}_{2}\right) / \mathrm{GCE}$ in all subsequent experiments.

\subsection{Analytical Performance of Poly $\left(\left[\mathrm{V}_{2} \mathrm{C}_{4}\left(\mathrm{mim}_{2}\right] \mathrm{Br}_{2}\right) / \mathrm{GCE}\right.$}

Under the optimized experimental conditions, the DPV curves of 4-NP at different concentrations were measured by poly $\left(\left[\mathrm{V}_{2} \mathrm{C}_{4}(\mathrm{mim})_{2}\right] \mathrm{Br}_{2}\right) / \mathrm{GCE}$ (Figure $\left.7 \mathrm{~A}\right)$. We observed a linear increase in the 
peak current with 4-NP concentration from 0.05 to $5 \mu \mathrm{M}$ (Figure 7B). We obtained a limit of detection (LOD) of $0.01 \mu \mathrm{M}(\mathrm{S} / \mathrm{N}=3)$ for 4-NP using the following linear regression equation: $\mathrm{I}(\mu \mathrm{A})=0.102$ $\mathrm{C}(\mu \mathrm{M})+0.0087\left(\mathrm{R}^{2}=0.9980\right)$. Compared with the other electrodes reported for 4-NP $[1,27,39-43]$, the poly $\left(\left[\mathrm{V}_{2} \mathrm{C}_{4}(\mathrm{mim})_{2}\right] \mathrm{Br}_{2}\right) / \mathrm{GCE}$ exhibited satisfactory analytical parameters (Table 1$)$. To demonstrate the advantage of poly $\left(\left[\mathrm{V}_{2} \mathrm{C}_{4}(\mathrm{mim})_{2}\right] \mathrm{Br}_{2}\right)$ sensor, we also investigated the linearity of a traditional cross-linker-based poly(EGDMA) sensor for 4-NP (Figure 7B). The poly(EGDMA)/GCE had a detection limit of $0.8 \mu \mathrm{M}(\mathrm{S} / \mathrm{N}=3)$ for a linear $4-\mathrm{NP}$ concentration range of 1.0 to $5 \mu \mathrm{M}$. The above findings clearly demonstrate higher sensitivity of poly $\left(\left[\mathrm{V}_{2} \mathrm{C}_{4}(\mathrm{mim})_{2}\right] \mathrm{Br}_{2}\right)$ based sensor towards 4-NP when compared with the poly(EGDMA)-based sensor.
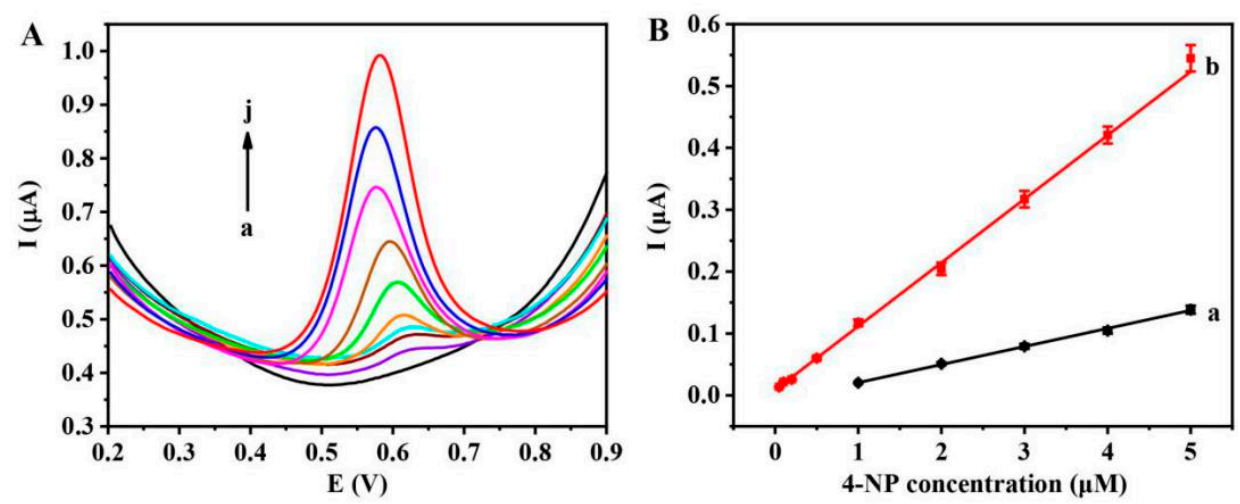

Figure 7. (A) Differential pulse voltammograms of poly $\left(\left[\mathrm{V}_{2} \mathrm{C}_{4}(\mathrm{mim})_{2}\right] \mathrm{Br}_{2}\right) / \mathrm{GCE}$ for $4-\mathrm{NP}$ from 0 (a), 0.05 (b), 0.1 (c), 0.2 (d), 0.5 (e), 1 (f), 2 (g), 3 (h), 4 (i), 5 (j) $\mu \mathrm{M}$. (B) Calibration plots for 4-NP with poly(EGDMA)/GCE (a) and poly $\left(\left[\mathrm{V}_{2} \mathrm{C}_{4}\left(\mathrm{mim}_{2}\right] \mathrm{Br}_{2}\right) / \mathrm{GCE}(\mathrm{b})(n=3)\right.$.

Table 1. Comparison with other electrochemical methods for the determination of 4-NP.

\begin{tabular}{|c|c|c|c|}
\hline Detection Method & Linear Range $(\mu \mathrm{M})$ & Detection Limit $(\mu \mathrm{M})$ & Ref. \\
\hline $\mathrm{CTAB}^{\mathrm{a}}$ / carbon paste electrode & $0.1-25$ & 0.01 & [1] \\
\hline AuNPs $/$ PILs ${ }^{b} /$ GCE & $0.1-120$ & 0.033 & [27] \\
\hline$\beta-\mathrm{CD}-\mathrm{SH}-\mathrm{GR}^{\mathrm{c}} / \mathrm{Au}$ electrode & $0.07-70$ & 0.061 & [39] \\
\hline $\mathrm{GR}^{\mathrm{d}}-\mathrm{DNA} / \mathrm{GCE}$ & $0.05-4$ & 0.01 & [40] \\
\hline MIL-101(Cr)@Rgo e /GCE & $0.1-12.5$ & 0.033 & [41] \\
\hline $\mathrm{MIP}^{\mathrm{f}} / \mathrm{AuNPs} / \mathrm{TiO}_{2} / \mathrm{GCE}$ & $0.95-480$ & 0.32 & [42] \\
\hline IL-FGNS g /GCE & $0.5-200$ & 0.058 & [43] \\
\hline $\operatorname{Poly}\left(\left[\mathrm{V}_{2} \mathrm{C}_{4}(\mathrm{mim})_{2}\right] \mathrm{Br}_{2}\right) / \mathrm{GCE}$ & $0.05-5$ & 0.01 & This work \\
\hline
\end{tabular}

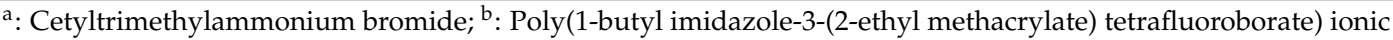
liquid hollow nanospheres; ${ }^{c}$ : Thiol- $\beta$-cyclodextrin $(\beta-\mathrm{CD}-\mathrm{SH})$ and graphene (GR) hybrid; ${ }^{\mathrm{d}}$ : Reduced graphene;

e: Chromium terephthalate metal-organic frameworks@reduced graphene oxide; f: Molecularly imprinted polymer;

$\mathrm{g}$ : Ionic liquid-functionalized grapheme nanosheet.

\subsection{Reproducibility, Stability and Selectivity of Poly $\left(\left[\mathrm{V}_{2} \mathrm{C}_{4}\left(\mathrm{mim}_{2}\right] \mathrm{Br} \mathrm{r}_{2}\right) / \mathrm{GCE}\right.$}

To study reproducibility and stability of poly $\left(\left[\mathrm{V}_{2} \mathrm{C}_{4}(\mathrm{mim})_{2}\right] \mathrm{Br}_{2}\right) / \mathrm{GCE}$, we performed DPV measurements of $2 \mu \mathrm{M}$ 4-NP solution using seven modified GCEs prepared independently. We obtained the relative standard deviation (RSD) as $4.35 \%$, confirming good reproducibility of the method. To check the stability, we carried out similar measurements with the poly $\left(\left[\mathrm{V}_{2} \mathrm{C}_{4}(\mathrm{mim})_{2}\right] \mathrm{Br}_{2}\right) / \mathrm{GCE}$ after storing for two weeks at $4{ }^{\circ} \mathrm{C}$, and found that the sensor could retain $93.7 \%$ of its original response $(2 \mu \mathrm{M} 4-\mathrm{NP})$, thus exhibiting good stability.

To evaluate the selectivity, we subjected our poly $\left(\left[\mathrm{V}_{2} \mathrm{C}_{4}(\mathrm{mim})_{2}\right] \mathrm{Br}_{2}\right) / \mathrm{GCE}$ to detect $4-\mathrm{NP}$ in presence of some possible interfering substances. Table 2 lists the tolerable ratio, which is defined as the maximum amount of foreign species resulting in an error lower than $\pm 5 \mathrm{c} / \mathrm{o}$ for detecting $2 \mu \mathrm{M}$ 4-NP. We found that 100-fold of $\mathrm{Na}^{+}, \mathrm{K}^{+}, \mathrm{Fe}^{2+}, \mathrm{Mg}^{2+}, \mathrm{Ni}^{2+}, \mathrm{Co}^{2+}, \mathrm{Cu}^{2+}, \mathrm{Cl}^{-}, \mathrm{NO}_{3}^{-}, \mathrm{SO}_{4}^{2-}$, and 10-fold 
hydroquinone, catechol, benzene, 1,2-dimethylbenzene, 2-nitroaniline, 3-nitroaniline and 4-nitroaniline had no influence on the determination of $2 \mu \mathrm{M} 4-\mathrm{NP}$ by the poly $\left(\left[\mathrm{V}_{2} \mathrm{C}_{4}(\mathrm{mim})_{2}\right] \mathrm{Br}_{2}\right) / \mathrm{GCE}$.

Table 2. Effects of foreign species on the determination of 4-NP.

\begin{tabular}{cc}
\hline Foreign Species & Tolerable Ratio \\
\hline $\mathrm{Na}^{+}, \mathrm{K}^{+}, \mathrm{Fe}^{2+}, \mathrm{Mg}^{2+}, \mathrm{Ni}^{2+}, \mathrm{Co}^{2+}, \mathrm{Cu}^{2+}, \mathrm{Cl}^{-}, \mathrm{NO}_{3}{ }^{-}, \mathrm{SO}_{4}{ }^{2-}$ & 100 \\
Hydroquinone, catechol, benzene, 1,2-dimethylbenzene, & 10 \\
2-nitroaniline, 3-nitroanilie, 4-nitroaniline & \\
\hline
\end{tabular}

\subsection{Analytical Application}

Furthermore, we evaluated the validity of the proposed method using the lake water samples collected from Nanhu Lake and rain water samples in Jiaxing city. The environmental water samples were filtered through $0.45 \mu \mathrm{m}$ filter before use. Since no 4-NP was detected in the water samples by the poly $\left(\left[\mathrm{V}_{2} \mathrm{C}_{4}(\mathrm{mim})_{2}\right] \mathrm{Br}_{2}\right) / \mathrm{GCE}$, we applied the standard addition method of spiking the samples with 4-NP for the method validation purpose. As shown in Table 3, the recovery was from $97.3 \%$ to $104.0 \%$, and the RSD was less than $4.47 \%$. This suggests the potential of the poly $\left(\left[\mathrm{V}_{2} \mathrm{C}_{4}(\mathrm{mim})_{2}\right] \mathrm{Br}_{2}\right) / \mathrm{GCE}$ for the detecting 4-NP in environmental water samples.

Table 3. Detection of 4-NP in water samples by poly $\left(\left[\mathrm{V}_{2} \mathrm{C}_{4}(\operatorname{mim})_{2}\right] \mathrm{Br}_{2}\right) / \mathrm{GCE}(n=3)$.

\begin{tabular}{ccccc}
\hline Sample & Added 4-NP $(\mu \mathbf{M})$ & Found 4-NP $(\mu \mathbf{M})$ & $\begin{array}{c}\text { Recovery } \\
\mathbf{( \% )}\end{array}$ & RSD (\%) \\
\hline \multirow{3}{*}{ Lake water } & 0.1 & 0.104 & 104.0 & 4.38 \\
& 1 & 0.991 & 99.1 & 4.47 \\
Rain water & 2 & 1.946 & 97.3 & 3.45 \\
& 0.1 & 0.0982 & 98.2 & 3.24 \\
& 1 & 1.031 & 103.1 & 4.43 \\
\hline
\end{tabular}

\section{Conclusions}

In an attempt to construct a sensitive electrochemical sensor for 4-NP, we synthesized a cross-linker-based PIL of poly $\left(\left[\mathrm{V}_{2} \mathrm{C}_{4}(\mathrm{mim})_{2}\right] \mathrm{Br}_{2}\right)$ as the sensing agent via a simple one-step free-radical polymerization method. Poly $\left(\left[\mathrm{V}_{2} \mathrm{C}_{4}(\mathrm{mim})_{2}\right] \mathrm{Br}_{2}\right) / \mathrm{GCE}$ with a large effective surface area exhibited good electrical conductivity and higher peak current response for 4-NP than that of poly(EGDMA)/GCE, indicating the advantage of poly $\left(\left[\mathrm{V}_{2} \mathrm{C}_{4}(\mathrm{mim})_{2}\right] \mathrm{Br}_{2}\right)$. In addition to excellent sensitivity, the poly $\left(\left[\mathrm{V}_{2} \mathrm{C}_{4}(\mathrm{mim})_{2}\right] \mathrm{Br}_{2}\right)$ based sensor also demonstrated 4-NP detection in environmental water samples.

Author Contributions: J.H., Y.Z., L.L., and R.C. designed the experiments; J.H. performed the experiments; J.H., H.D., Y.Z., Y.Y., H.W., X.Z., L.L., G.Z., and L.G. analyzed the data; J.H., Y.Z., and L.L. wrote the paper; and all authors reviewed, edited, and approved the manuscript.

Funding: This work was supported by the National Natural Science Foundation of China (No. 21507041, 21677060), the Zhejiang Provincial Natural Science Foundation of China under Grant No. LY16B050007 and LQ19B050002, the Open Project of MOE Key Laboratory for Analytical Science of Food Safety and Biology (No. FS18011), and the Program for Science and Technology of Jiaxing (No. 2018AY11002, 2017AY33034).

Conflicts of Interest: The authors declare no conflict of interest.

\section{References}

1. Lu, Q.; Zhang, W.; Wang, Z.; Yu, G.; Yuan, Y.; Zhou, Y. A facile electrochemical sensor for nonylphenol determination based on the enhancement effect of cetyltrimethylammonium bromide. Sensors 2013, 13, 758-768. [CrossRef] 
2. Soares, A.; Guieysse, B.; Jefferson, B.; Cartmell, E.; Lester, J. Nonylphenol in the environment: A critical review on occurrence, fate, toxicity and treatment in wastewaters. Environ. Int. 2008, 34, 1033-1049. [CrossRef]

3. Preuss, T.G.; Gehrhardt, J.; Schirmer, K.; Coors, A.; Rubach, M.; Russ, A.; Jones, P.D.; Giesy, J.P.; Ratte, H.T. Nonylphenol isomers differ in estrogenic activity. Environ. Sci. Technol. 2006, 40, 5147-5153. [CrossRef] [PubMed]

4. Céspedes, R.; Skryjová, K.; Raková, M.; Zeravik, J.; Fránek, M.; Lacorte, S.; Barceló, D. Validation of an enzyme-linked immunosorbent assay (ELISA) for the determination of 4-nonylphenol and octylphenol in surface water samples by LC-ESI-MS. Talanta 2006, 70, 745-751. [CrossRef]

5. Lopes, D.; Dias, A.N.; Merib, J.; Carasek, E. Hollow-fiber renewal liquid membrane extraction coupled with 96-well plate system as innovative high-throughput configuration for the determination of endocrine disrupting compounds by high-performance liquid chromatography-fluorescence and diode array detection. Anal. Chim. Acta 2018, 1040, 33-40.

6. Pastor-Belda, M.; Viñas, P.; Campillo, N.; Hernández-Córdoba, M. Magnetic solid phase extraction with $\mathrm{CoFe}_{2} \mathrm{O}_{4}$ /oleic acid nanoparticles coupled to gas chromatography-mass spectrometry for the determination of alkylphenols in baby foods. Food. Chem. 2017, 221, 76-81. [CrossRef] [PubMed]

7. Han, S.; Li, X.; Wang, Y.; Su, C. A core-shell $\mathrm{Fe}_{3} \mathrm{O}_{4}$ nanoparticle-CdTe quantum dot-molecularly imprinted polymer composite for recognition and separation of 4-nonylphenol. Anal. Methods 2014, 6, 2855-2861. [CrossRef]

8. Ai, J.; Guo, H.; Xue, R.; Wang, X.; Lei, X.; Yang, W. A self-probing, gate-controlled, molecularly imprinted electrochemical sensor for ultrasensitive determination of p-nonylphenol. Electrochem. Commun. 2018, 89, 1-5. [CrossRef]

9. Qin, J.; Guo, J.; Xu, Q.; Zheng, Z.; Mao, H.; Yan, F. Synthesis of pyrrolidinium-type poly(ionic liquid) membranes for antibacterial applications. ACS Appl. Mater. Int. 2017, 9, 10504-10511. [CrossRef] [PubMed]

10. Zhou, D.; Liu, R.; Zhang, J.; Qi, X.; He, Y.; Li, B.; Yang, Q.; Hu, Y.; Kang, F. In situ synthesis of hierarchical poly(ionic liquid)-based solid electrolytes for high-safety lithium-ion and sodium-ion batteries. Nano Energy 2017, 33, 45-54. [CrossRef]

11. Osada, I.; de Vries, H.; Scrosati, B.; Passerini, S. Ionic-Liquid-Based Polymer Electrolytes for Battery Applications. Angew. Chem. Int. Ed. 2016, 55, 500-513. [CrossRef]

12. Qian, W.; Texter, J.; Yan, F. Frontiers in poly(ionic liquid)s: Syntheses and applications. Chem. Soc. Rev. 2017, 46, 1124-1159. [CrossRef]

13. Wang, P.; Wang, T.; Lin, W.; Lin, H.; Lee, M.; Yang, C. Crosslinked polymer ionic liquid/ionic liquid blends prepared by photopolymerization as solid-state electrolytes in supercapacitors. Nanomaterials 2018, 8, 225. [CrossRef] [PubMed]

14. Gao, C.J.; Chen, G.J.; Wang, X.C.; Li, J.; Zhou, Y.; Wang, J. A hierarchical meso-macroporous poly(ionic liquid) monolith derived from a single soft template. Chem. Commun. 2015, 51, 4969-4972. [CrossRef]

15. Suo, X.; Xia, L.; Yang, Q.; Zhang, Z.; Bao, Z.; Ren, Q.; Yang, Y.; Xing, H. Synthesis of anion-functionalized mesoporous poly(ionic liquid)s via a microphase separation-hypercrosslinking strategy: Highly efficient adsorbents for bioactive molecules. J. Mater. Chem. A 2017, 5, 14114-14123. [CrossRef]

16. Wu, M.; Wang, L.; Zeng, B.; Zhao, F. Ionic liquid polymer functionalized carbon nanotubes-doped poly(3,4-ethylenedioxythiophene) for highly-efficient solid-phase microextraction of carbamate pesticides. J. Chromatogr. A 2016, 1444, 42-49. [CrossRef] [PubMed]

17. Wang, R.; Yuan, Y.; Yang, X.; Han, Y.; Yan, H. Polymethacrylate microparticles covalently functionalized with an ionic liquid for solid-phase extraction of fluoroquinolone antibiotics. Microchim. Acta 2015, 182, 2201-2208. [CrossRef]

18. Chen, L.; Mei, M.; Huang, X.; Yuan, D. Sensitive determination of estrogens in environmental waters treated with polymeric ionic liquid-based stir cake sorptive extraction and liquid chromatographic analysis. Talanta 2016, 152, 98-104. [CrossRef] [PubMed]

19. Liu, C.; Liao, Y.; Huang, X. Fabrication of polymeric ionic liquid-modified magnetic adsorbent for extraction of apolar and polar pollutants in complicated samples. Talanta 2017, 172, 23-30. [CrossRef]

20. Liu, C.; Deng, Q.; Fang, G.; Dang, M.; Wang, S. Capillary electrochromatography immunoassay for alpha-fetoprotein based on poly(guanidinium ionic liquid) monolithic material. Anal. Biochem. 2017, 530, 50-56. [CrossRef] 
21. Wang, Q.; Yun, Y. Nonenzymatic sensor for hydrogen peroxide based on the electrodeposition of silver nanoparticles on poly(ionic liquid)-stabilized graphene sheets. Microchim. Acta 2013, 180, 261-268. [CrossRef]

22. Sánchez-Paniagua López, M.; López-Ruiz, B. Electrochemical biosensor based on ionic liquid polymeric microparticles. An analytical platform for catechol. Microchem. J. 2018, 138, 173-179. [CrossRef]

23. Cui, K.; Lu, X.; Cui, W.; Wu, J.; Chen, X.; Lu, Q. Fluorescent nanoparticles assembled from a poly(ionic liquid) for selective sensing of copper ions. Chem. Commun. 2011, 47, 920-922. [CrossRef] [PubMed]

24. Wang, Y.; Li, C.; Wu, T.; Ye, X. Polymerized ionic liquid functionalized graphene oxide nanosheets as a sensitive platform for bisphenol A sensing. Carbon 2018, 129, 21-28. [CrossRef]

25. Yu, Y.; Yu, C.; Yin, T.; Ou, S.; Sun, X.; Wen, X.; Zhang, L.; Tang, D.; Yin, X. Functionalized poly (ionic liquid) as the support to construct a ratiometric electrochemical biosensor for the selective determination of copper ions in AD rats. Biosens. Bioelectron. 2017, 87, 278-284. [CrossRef]

26. Li, J.; Li, Q.; Zeng, Y.; Tang, T.; Pan, Y.; Li, L. An electrochemical sensor for the sensitive determination of phenylethanolamine A based on a novel composite of reduced graphene oxide and poly (ionic liquid). RSC Adv. 2015, 5, 717-725. [CrossRef]

27. Ren, J.; Gu, J.; Tao, L.; Yao, M.; Yang, X.; Yang, W. A novel electrochemical sensor of 4-nonylphenol based on a poly(ionic liquid) hollow nanosphere/gold nanoparticle composite modified glassy carbon electrode. Anal. Methods 2015, 7, 8094-8099. [CrossRef]

28. Ding, S.; Hu, X.; Guan, P.; Zhang, N.; Li, J.; Gao, X.; Zhang, X.; Ding, X.; Du, C. Preparation of surface-imprinted microspheres using ionic liquids as novel cross-linker for recognizing an immunostimulating peptide. J. Mater. Sci. 2017, 52, 8027-8040. [CrossRef]

29. Ma, W.W.; Row, K.H. Solid-phase extraction of chlorophenols in seawater using a magnetic ionic liquid molecularly imprinted polymer with incorporated silicon dioxide as a sorbent. J. Chromatogr. A 2018, 1559, 78-85. [CrossRef] [PubMed]

30. Zhu, X.; Zeng, Y.; Zhang, Z.; Yang, Y.; Zhai, Y.; Wang, H.; Liu, L.; Hu, J.; Li, L. A new composite of graphene and molecularly imprinted polymer based on ionic liquids as functional monomer and cross-linker for electrochemical sensing 6-benzylaminopurine. Biosens. Bioelectron. 2018, 108, 38-45. [CrossRef] [PubMed]

31. Yuan, J.; Antonietti, M. Poly (ionic liquid) latexes prepared by dispersion polymerization of ionic liquid monomers. Macromolecules 2011, 44, 744-750. [CrossRef]

32. Zhang, Q.; Wu, S.; Zhang, L.; Lu, J.; Verproot, F.; Liu, Y.; Xing, Z.; Li, J.; Song, X. Fabrication of polymeric ionic liquid/graphene nanocomposite for glucose oxidase immobilization and direct electrochemistry. Biosens. Bioelectron. 2011, 26, 2632-2637. [CrossRef]

33. Mao, Y.; Bao, Y.; Gan, S.; Li, F.; Niu, L. Electrochemical sensor for dopamine based on a novel graphene-molecular imprinted polymers composite recognition element. Biosens. Bioelectron. 2011, 28, 291-297. [CrossRef]

34. Ana-Maria, G.; Lucian, R.; Mihaela, B.; Ioan, B.; Camelia, B. Sensitive detection of endocrine disrupters using ionic liquid-single walled carbon nanotubes modified screen-printed based biosensors. Talanta 2011, 85, 2007-2013.

35. Filipecka, K.; MiedzińSki, R.; Sitarz, M.; Filipecki, J.; Makowska-Janusik, M. Optical and vibrational properties of phosphorylcholine-based contact lenses-experimental and theoretical investigations. Spectrochim. Acta A 2017, 176, 83-90. [CrossRef] [PubMed]

36. Anson, F.C. Application of Potentiostatic Current Integration to the Study of the Adsorption of Cobalt(III)-(Ethylenedinitrilo(tetraacetate) on Mercury Electrodes. Anal. Chem. 1964, 36, 932-934. [CrossRef]

37. Li, S.; Lei, S.; Yu, Q.; Zou, L.; Ye, B. A novel electrochemical sensor for detecting hyperin with a nanocomposite of $\mathrm{ZrO}_{2}$-SDS-SWCNTs as decoration. Talanta 2018, 185, 453-460. [CrossRef] [PubMed]

38. Su, D.; Zhang, Y.; Wang, Z.; Wan, Q.; Yang, N. Decoration of graphene nano platelets with gold nanoparticles for voltammetry of 4-nonylphenol. Carbon 2017, 117, 313-321. [CrossRef]

39. Xue, F.; Gao, Z.; Sun, X.; Yang, Z.; Yi, L.; Chen, W. Electrochemical determination of environmental hormone nonylphenol based on composite film modified gold electrode. J. Electrochem. Soc. 2015, 162, H338-H344. [CrossRef]

40. Zeng, L.; Zhang, A.; Zhu, X.; Zhang, C.; Liang, Y.; Nan, J. Electrochemical determination of nonylphenol using differential pulse voltammetry based on a graphene-DNA-modified glassy carbon electrode. J. Electroanal. Chem. 2013, 703, 153-157. [CrossRef] 
41. Zhang, Y.; Yan, P.; Wan, Q.; Yang, N. Integration of chromium terephthalate metal-organic frameworks with reduced graphene oxide for voltammetry of 4-nonylphenol. Carbon 2018, 134, 540-547. [CrossRef]

42. Huang, J.; Zhang, X.; Liu, S.; Lin, Q.; He, X.; Xing, X.; Lian, W.; Tang, D. Development of molecularly imprinted electrochemical sensor with titanium oxide and gold nanomaterials enhanced technique for determination of 4-nonylphenol. Sens. Actuators B-Chem. 2011, 152, 292-298. [CrossRef]

43. Meng, X.; Yin, H.; Xu, M.; Ai, S.; Zhu, J. Electrochemical determination of nonylphenol based on ionic liquid-functionalized graphene nanosheet modified glassy carbon electrode and its interaction with DNA. J. Solid State Electr. 2012, 16, 2837-2843. [CrossRef]

(c) 2019 by the authors. Licensee MDPI, Basel, Switzerland. This article is an open access article distributed under the terms and conditions of the Creative Commons Attribution (CC BY) license (http://creativecommons.org/licenses/by/4.0/). 